\title{
IDENTIFIKASI ALIRAN PANAS BAWAH PERMUKAAN DI DESA LEMBA HARAPAN KABUPATEN TOLITOLI MENGGUNAKAN METODE GEOLISTRIK HAMBATAN JENIS
}

\author{
Muhammad Ifal Armada, Moh. Dahlan Th. Musa, Maskur, Badaruddin \\ Jurusan Fisika, FMIPA Universitas Tadulako, Palu
}

e-mail:muhammadifalarmada230995@gmail.com

\begin{abstract}
Research on geothermal energy in the village of Lemba Harapan, the hope of Tolitoli Distric, is to identify the subsurface heat flow that has been compeleted. This study uses a type of geoelectric resistance method with a Wenner configuration. Data collection was carried out as many as 4 tracks spread across the research area. Processing data using Surferl1 software to abtain result in the form of cross section with calculation of formation factors an Res 2 dinv software so that the resistance value of the type layer with range $24,44-61,1 \Omega \mathrm{m}$ is assumed to be the heat flow found below the surface
\end{abstract}

Keywords :Geoelectric, Resistivity, Heat flow

\begin{abstract}
ABSTRAK
Penelitian tentang panasbumi di Desa Lemba Harapan Kabupaten Tolitoli telah selesai dilakukan dengan menggunakan metode geolistrik hambatan jenis dengan konigurasi Wenner. Penelitian ini bertujuan untuk mengidentifikasi aliran panas bawah permukaan. Pengambilan data dilakukan sebanyak 4 lintasan yang tersebar di daerah penelitian. Pengolahan data menggunakan software Surfer11 unuk memperoleh hasil berupa penampang dengan perhitungan faktor formasi dan software Res2dinv sehingga diperoleh nilai hambatan jenis lapisan dengan range $24,44-61,1 \Omega \mathrm{m}$ yang diduga sebagai aliran panas yang tedapat di bawah permukaan.
\end{abstract}

Kata Kunci : Geolistrik, Hambatan Jenis, Aliran Panas 


\section{PENDAHULUAN}

Kebutuhan manusia terhadap energi setiap tahun mengalami peningkatan, sedangkan cadangan sumber energi semakin berkurang. Hal ini membuat manusia berusaha untuk mencari sumber energi alternatif yang ramah lingkungan serta dapat dimanfaatkan untuk memenuhi kebutuhan manusia akan energi. Panasbumi merupakan salah satu sumber daya alam yang memiliki potensi sangat besar untuk dimanfaatkan sebagai salah satu sumber energi alternatif (Minarto 2007). Energi panasbumi (geothermal) berasal dari bahasa yunani yaitu gheo yang berarti bumi dan termal berarti panas. Panasbumi bisa didefinisikan dengan panas yang berasal dari bumi, dimana energi tersebut bersih dan ramah lingkungan. Sumber energi ini terkandung didalam air panas, uap air, dan batuan bersama mineral dan gas lainnya yang tidak dapat dipisahkan dalam suatu sistem (Lange dan Labedeva 1991).

Berdasarkan peta Geologi Lembar Tolitoli Sulawesi Utara, batuan di daerah tersebut adalah jenis batuan terobosan (intrusif) dimana terjadi proses magmatisme yaitu intrusi magma menerobos batuan tua dan menjadi batuan beku. Dari hasil pembekuan batuan inilah yang dipekirakan sebagai sumber panas yang kemudian akan muncul di permukaan berupa sumber mata air panas yang keluar melalui rekahan-rekahan atau patahan (Wati, 2015 ).

Indikasi keberadaan panas bumi di Desa Lemba Harapan, tepatnya berada di dusun Tande, dapat dilihat dari adanya sumber mata air panas yang muncul di permukaan. Terdapat tiga mata air panas yang keluar melalui celah batuan dengan jarak yang saling berdekatan satu sama lain. Hingga saat ini belum ada data penelitian tentang identifikasi panas bumi di Desa Lemba Harapan. Untuk memberikan informasi, serta kemungkinan pemanfaatannya sebagai salah satu energi alternatif, maka perlu dilakukan penelitian. Salah satu metode geofisika yang dapat digunakan untuk mengetahui aliran panasbumi adalah metode Geolistrik.

Penelitian tentang sebaran panasbumi menggunakan metode geolistrik hambatan jenis, pernah dilakukan oleh Wati (2015) di Desa Mapane Tambu. Pada penelitiannya sebaran panas bumi terdapat pada lapisan yang tersusun atas batu pasir dan lempung pasiran dengan nilai hambatan jenisnya adalah $1 \Omega \mathrm{m}-3,3 \Omega \mathrm{m}$. Sementara itu Arif (2015) juga melakukan penelitian menentukan sebaran panas bumi menggunakan metode yang sama. Pada penelitiannya sebaran panas bumi terdapat pada lapisan pasir lempung pada kedalaman $\pm 8 \mathrm{~m}$ dari atas permukaan dengan nilai hambatan jenisnya $1 \Omega \mathrm{m}-10 \Omega \mathrm{m}$.

Bumi memiliki panas yang berasal dari 2 sumber, yaitu dari dalam bumi (internal heat) dan matahari (external heat) (Lange, 1991). Panasbumi adalah sumber energi yang terkandung di dalam air panas, uap air dan batuan bersama mineral ikutan dan gas lainnya yang secara genetik semuanya tidak dapat dipisahkan dalam suatu sistem panasbumi. Sumber energi panasbumi (geotermal) berasal dari aktivitas tektonik yag terjadi di dalam inti bumi, terbentuk secara alami sejak planet ini diciptakan. Energi panasbumi, terdapat pada batuan berbentuk cair, dan berbagai jenis logam yang memiliki suhu sangat tinggi, berasal dari pemanasan batuan dan air bersama unsur-unsur lain yang tersimpan di dalam kerak bumi. Panasbumi juga berasal dari panas matahari yang diserap oleh permukaan bumi. Bumi rata-rata menerima $10^{21}$ kalori panas per tahun dari matahari. Energi panasbumi cukup ekonomis dan ramah lingkungan, tetapi terbatas hanya pada dekat area perbatasan lapisan tektonik. Dikatakan ramah lingkungan karena unsur-unsur yang berasosiasi dengan energi panas tidak membawa dampak lingkungan atau berada dalam batas yang berlaku (Ilyas, 2012). 
Energi panasbumi telah banyak dipergunakan untuk memanaskan (air atau ruangan ketika musim dingin) sejak peradaban romawi, namun sekarang lebih populer untuk menghasilkan energi listrik. Gejala panasbumi pada umumnya tampak di permukaan bumi berupa mata air panas, kubangan lumpur panas, (mud pools) dan kolam air panas (Moedioyono, 2010). Sumberdaya panasbumi pada umumnya berkaitan dengan mekanisme pembentukan magma dan kegiatan vulkanisme. Walaupun secara umum di bawah permukaan terdapat sumber panas, namun tidak semua lokasi menyimpan energi panas bumi. Energi panas bumi hanya terdapat pada lokasi yang memiliki sistem panas bumi seperti yang ditunjukkan pada Gambar

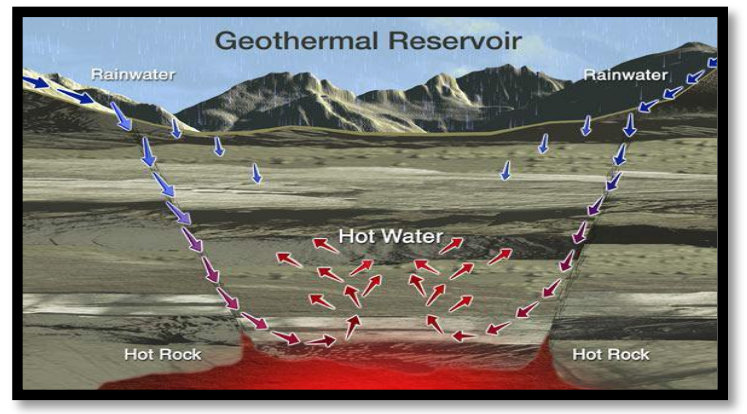

Gambar 1 : Skema sumber panas bumi (Eko Minarto 2007).

Kondisi ideal geologi yang memenuhi persyaratan daerah panas bumi (geotermal reservoar) yang dapat menghasilkan uap panas adalah adanya sumber panas (heat source), adanya batuan reservoar yang permeabilitas tinggi berisi fluida panas (ada pengisian kembali air dingin) dan air yang membawa panas dari reservoar ke permukaan bumi.

Reservoir panasbumi yang paling banyak dimanfaatkan hingga saat ini adalah reservoir dari sistem hidrothermal, yaitu sistem panasbumi dimana reservoirnya mengandung uap, air atau campuran keduanya, tergantung tekanan dan temperatur reservoirnya. Pada dasarnya sistim panasbumi jenis hidrothermal terbentuk sebagai hasil perpindahan panas dari suatu sumber panas ke sekelilingnya yang terjadi secara konduksi dan secara konveksi. Perpindahan panas secara konduksi terjadi melalui batuan, sedangkan perpindahan panas secara konveksi terjadi karena adanya kontak antara air dengan suatu sumber panas. Perpindahan panas secara konveksi pada dasarnya terjadi karena gaya apung. Air karena gaya gravitasi selalu mempunyai kecenderungan untuk bergerak kebawah, akan tetapi apabila air tersebut kontak dengan suatu sumber panas maka akan terjadi perpindahan panas sehingga temperatur air menjadi lebih tinggi dan air menjadi lebih ringan. Keadaan ini menyebabkan air yang lebih panas bergerak ke atas dan air yang lebih dingin bergerak turun ke bawah, sehingga teriadi sirkulasi air atau arus konveksi.

Menururt Telford (1990), aliran listrik di dalam batuan dan mineral dapat digolongkan menjadi 3 macam, yaitu konduksi secara elektronik, konduksi secara elektrolitik dan konduksi secara dielektrik.

a. konduksi secara elektronik

Konduksi ini terjadi jika batuan dan mineral mempunyai banyak elektron bebas sehingga arus listrik mudah dialirkan dalam batuan atau mineral oleh elektron-elektron bebas tersebut.

b. konduksi secara elektrolitik

Batuan biasanya bersifat forus dan memiliki pori-pori yang terisi oleh fluida, terutama air. Batuan-batuan tersebut menjadi konduktor elektrolitik, dimana konduksi arus listrik dibawa oleh ion-ion elektrolitik dalam air. Konduktivitas dan hambatan jenis batuan porus bergantung pada volume dan susunan pori-porinya. Konduktivitas akan semakin besar jika kandungan air dalam batuan bertambah banyak.

c. konduksi secara dielektrik

Konduksi pada batuan atau mineral bersifat dielektrik terhadap aliran listrik, 
artinya batuan atau mineral tersebut mempunyai elektron bebas sedikit, bahkan tidak ada sama sekali. Tetapi karena adanya pengaruh medan listrik dari luar maka elektron dalam bahan berpindah dan berkumpul terpisah dari inti, seingga terjadi polarisasi. Peristiwa ini tergantung pada konduksi dielektrik masing-masing batuan yang bersangkutan.

Berdasarkan harga hambatan jenisnya batuan dan mineral digolongkan menjadi tiga (Prameswari dkk, 2012) yaitu:
a. Konduktor baik
$: 10^{-6} \Omega \mathrm{m}<\rho<1 \Omega \mathrm{m}$
b. Pertengahan
$: 1 \Omega \mathrm{m}<\rho<10^{7} \Omega \mathrm{m}$
c. Isolator $: \rho>10^{7} \Omega \mathrm{m}$

$$
\mathrm{F}=\frac{\rho}{\rho w}=\frac{\alpha}{\emptyset^{-m}}
$$

Faktor formasi dapat digunakan untuk pendugaan zona aquifer karena besaran tersebut berefleksi sebagai porositas pada batuan sedimen maupun batuan beku yang mengalami rekahan.

Pada eksplorasi hidrogeologi, pengukuran hambatan jenis $\rho$ dapat dilakukan secara langsung di lapangan, yaitu dengan metode hambatan jenis. Hambatan jenis air pengisi pori $\rho_{\mathrm{w}}$, selain dapat diukur secara langsung, dapat juga diukur menggunakan persamaan:

$$
\rho_{\mathrm{w}=10000 / \mathrm{DHL}} \quad(2.3)
$$

Dari kedua persamaan tersebut dapat dihitung nilai faktor formasi (F) menggunakan persamaan (2.2). Beberapa kesimpulan nilai faktor formasi dari studi hidrogeologi yang diperoleh (Taib, 1999) seperti pada tabel 2.1 halaman selanjutnya.
Tabel 1 Klasifikasi pendugaan faktor formasi untuk batuan sedimen

\begin{tabular}{|c|c|c|c|}
\hline $\begin{array}{c}\text { N } \\
\text { 0. }\end{array}$ & F & Formasi & $\begin{array}{c}\text { Aquifer/Aquic } \\
\text { lude }\end{array}$ \\
\hline 1 & $\leq 1$ & Clay & Aquiclude \\
\hline 3 & $1-1,5$ & $\begin{array}{c}\text { Peat, } \\
\text { clayey } \\
\text { sand atau }\end{array}$ & Aquiclude \\
\hline 4 & 3 & $\begin{array}{c}\text { Medium }- \\
\text { sand } \\
\text { find sand }\end{array}$ & $\begin{array}{c}\text { Poor to } \\
\text { medium } \\
\text { aquifer }\end{array}$ \\
\hline 5 & 4 & $\begin{array}{c}\text { Coarse } \\
\text { productive } \\
\text { aquifer }\end{array}$ \\
\hline 6 & 5 & Grand & $\begin{array}{c}\text { Productive } \\
\text { aquifer }\end{array}$ \\
\hline
\end{tabular}

(Sumber: Taib, 1999)

Geolistrik adalah salah satu metode dalam geofisika yang mempelajari sifat aliran listrik di dalam bumi. pendeteksian di atas permukaan meliputi pengukuran medan potensial, dan arus yang terjadi baik secara alamiah maupun akibat penginjeksian arus ke dalam bumi. Metode ini sering digunakan baik dalam survey geologi maupun eksplorasi. Hal ini disebabkan karena metode geolistrik sangat bagus untuk mengetahui kondisi atau struktur geologi bawah permukaan berdasarkan variasi hambatan jenis batuannya. Terutama untuk daerah yang mempunyai kontras hambatan jenis yang cukup jelas terhadap sekitarnya, misalnya untuk keperluan eksplorasi air tanah, dan panas bumi (geothermal) (Haeruddin, 2008). Bentuk susunan elektroda pada pengukuran geolistrik ditunjukkan pada gambar 2 .

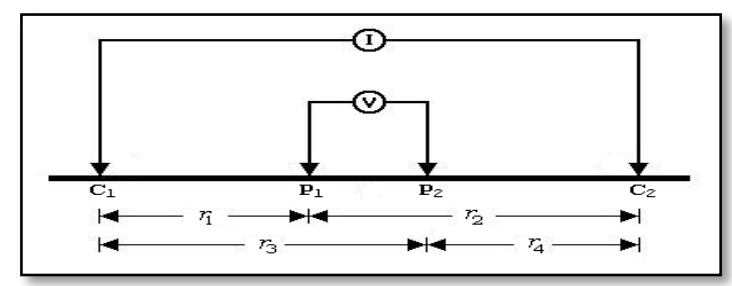

Gambar 2 Bentuk susunan elektroda pada pengukuran geofisika (Santoso, 2002). 
Prinsip dasar metode ini adalah menginjeksikan arus listrik ke dalam bumi menggunakan 2 buah elektroda arus, kemudian mengukur beda potensial melalui 2 buah elektroda lainnya di permukaan bumi. Arus listrik yang diinjeksikan akan mengalir melalui lapisan batuan bawah permukaan, dan menghasilkan data beda potensial yang bergantung pada hambatan jenis (resistivity) dari batuan yang dilaluinya.

Dari besarnya arus dan beda potensial yang terukur maka nilai resistivitas dapat dihitung dengan menggunakan persamaan:

$$
\rho_{a}=K \frac{\Delta V}{I}
$$

$\mathrm{K}$ merupakan faktor geometri yang tergantung pada penempatan elektroda arus maupun elektroda potensial pada permukaan.

$$
K=\frac{2 \pi}{\left\{\left(\frac{1}{r_{1}}-\frac{1}{r_{2}}\right)-\left(\frac{1}{r_{3}}-\frac{1}{r_{4}}\right)\right\}}
$$

Metode Automatic Array Scanning (AAS) adalah metode geolistrik hambatan jenis yang melakukan pengukuran berulang-ulang serta berurutan dengan menggunakan kedalaman penetrasi tertentu. Dimana $\mathrm{C}_{1} \mathrm{C}_{2}$ adalah elektroda arus dan $\mathrm{P}_{1} \mathrm{P}_{2}$ adalah elktroda potensial, sedangkan a adalah jarak antara elektroda. Jarak ke 4 elektroda baik arus maupun potensial adalah sama, dengan elektroda potensial berada ditengah-tengah elektroda arus. Dalam pengoperasian dilapangan ke 4 elektroda harus dipindahkan secara serentak untuk memperoleh hasil pengukuran dengan a yang berbeda. spasi antar elektroda pada konfigurasi wenner adalah a, sehingga faktor geometri dari persamaan (3.0) adalah

$$
\mathrm{K}=2 \pi \mathrm{a}
$$

\section{METODE PENELITIAN}

\section{Lokasi Penelitian}

Secara geografis, lokasi penelitian berada pada koordinat $0^{\circ} 42^{\prime} 30^{\prime}$ ' - $0^{\circ} 42^{\prime} 45^{\prime}$ ' LU dan $120^{\circ} 12^{\prime} 45^{\prime}$ ' - 120'13'0' 'BT atau lebih tepatnya berada di Desa Lemba Harapan, Kecamatan Dampal-Selatan, Kabupaten Tolitoli. Untuk melihat secara jelas kondisi lokasi penelitian, ditampilkan peta lokasi penelitian pada gambar 3 di bawah.

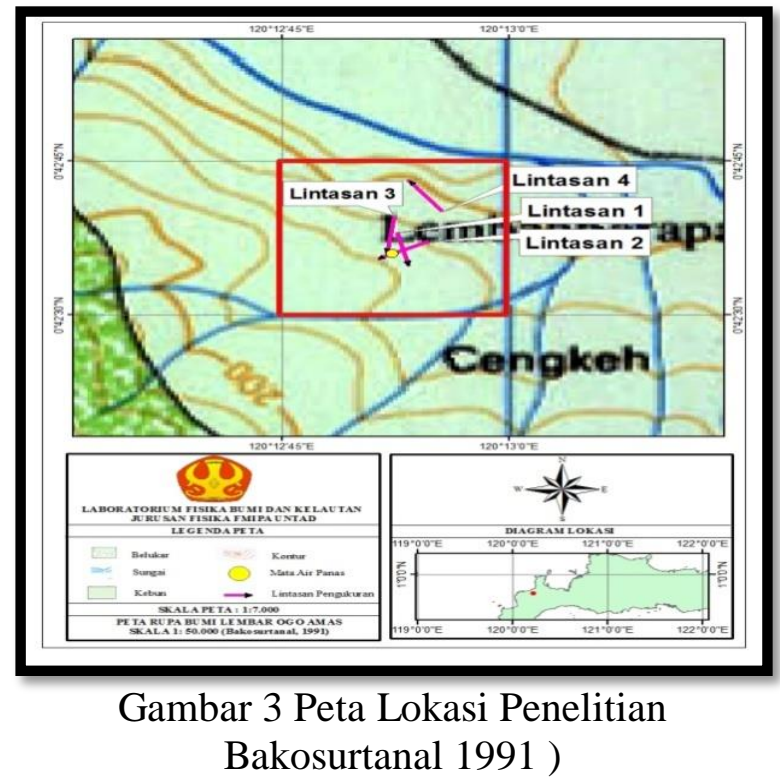

\section{Alat dan Bahan}

Alat dan Bahan yang digunakan dalam penelitian ini yaitu :

a. Satu set alat ukur geolistrik yang terdiri dari :
1) 1 set Resistivitimeter
2) Kabel 4 gulung
3) Elektroda 25 buah
4) Sumber arus listrik (accu)
5) Kabel penghubung

b. Meteran untuk menentukan jarak spasi antara elektroda

c. Global Positioning System (GPS) untuk menentukan posisi dan elevasi tiap elektroda

d. Kompas Geologi untuk menentukan arah bentangan

e. Peta Rupa Bumi Indonesia lembar Ogoamas skala 1:50.000 
f. Palu untuk menancapkan elektroda arus dan potensial ke dalam tanah

g. Program Res2dinv untuk melakukan pengolahan data

h. Program Surferll berfungsi untuk membuat penampang faktor formasi

i. Alat tulis dan tabel data berfungsi untuk mencatat data hasil pengukuran

\section{Prosedur Pelaksanaan Penelitian}

1. Survei Pendahuluan

Survei pendahuluan perlu dilakukan untuk memperoleh gambaran kondisi geologi dan topografi daerah penelitian dan untuk menentukan titik-titik lokasi pengukuran.

2. Prosedur Pengambilan Data

Pengambilan data di lapangan menggunakan metode geolistrik hambatan jenis, yaitu dengan Konfigurasi Wenner. Adapun langkahlangkah yang dilakukan dalam melakukan pengukuran di lapangan adalah sebagai berikut:

a. Menentukan posisi titik pengukuran.

b. Menentukan arah bentangan.

c. Memasang elektroda $\mathrm{C}_{1} \mathrm{C}_{2}$ dan $\mathrm{P}_{1}$ $\mathrm{P}_{2}$ dengan jarak spasi sejauh 5 meter serta mencatat koordinat tiap elektroda

d. Merangkai alat Resistivitimeter dengan mengubungkan kabel arus pada elektroda $\mathrm{C} 1$ dan $\mathrm{C} 2$ serta kabel potensial pada elektrida P1 dan P2.

e. Melakukan pengukuran besar arus (I) dan beda potensial (V).

f. Selanjutnya memindahkan kabel arus dan potensial ke elektroda berikutnya. Pemindahan ini dilakukan hingga ke elektroda paling ujung lintasan $(22,23,24$, dan 25).

g. Pengukuran diulangi dengan memperbesar spasi antar elektoda arus dan potensial sampai $\mathrm{n}=8$ kemudian mengulangi langkah (e).

h. Data yang diperoleh dari pengukuran di lapangan adalah data arus (I) dan beda potensial (V) serta jarak antar elektroda.

i. Untuk menghindari adanya kesalahan dalam pengukuran, maka pengukuran dilakukan berulang sebanyak $3 \mathrm{x}$.

\section{Pengolahan Data dan Interpretasi Data}

Pengolahan dan interpretasi data dilakukan dengan langkah-langkah sebagai berikut:

1) Menginput data lapangan ke dalam software MS Excel

2) Menghitung faktor geometri (K) dari hasil pengukuran dengan menggunakan Persamaan (3.1).

3) Menghitung nilai hambatan jenis $\rho_{a}$ dari hasil pengukuran dengan menggunakan Persamaan (2.9).

4) Memindahkan data hasil perhitungan dari Sotware MS Excel ke dalam software Notepad.p

5) Data beda potensial (V), arus (I), hambatan jenis semu $\left(\rho_{\mathrm{a}}\right)$ dan faktor geometri $(\mathrm{K})$ yang diperoleh dari hasil pengukuran kemudian diinversikan dengan program Res2dinv dan divisualisasikan menggunakan software Surfer11. Selanjutnya dilakukan modifikasi menggunakan software CorelDRAWX6 untuk membuat tampilannya lebih baik.

6) Hasil yang diperoleh dari program inversi berupa variasi nilai hambatan jenis, kedalaman dan ketebalan lapisan setiap bentangan yang kemudian dianalisa dan diinterpretasikan.

7) Diperoleh hasil berupa aliran panas bawah permukaan, berdasarkan visualisasi model penampang dari hasil perhitungan niali faktor formasi.

8) Untuk memperoleh hasil interpretasi yang lebih akurat, maka diperlukan data-data pendukung yang berhubungan dengan kondisi daerah penelitian diantaranya, peta geologi, peta rupa bumi dan sampel air yang diperoleh dari pengukuran langsung berupa nilai DHL. 


\section{HASIL DAN PEMBAHASAN}

Pengukuran ini dilakukan untuk meperoleh gambaran tentang lapisan bawah permukaan yang bertujuan untuk mendapatkan informasi tentang aliran panas bawah permukaan di sekitar area panas bumi desa Lemba Harapan Kab. Tolitoli. Pengukuran ini dilakuakan menggunakan metode Automatic Array Scanning (AAS) konfigurasi Wenner, dengan pengambilan data sebanyak 4 lintasan. Setiap lintasan terdiri dari 25 elektoda dengan spasi antar elektrodanya (a) sebesar 5 meter, sehingga total panjang lintas annya sejauh 120 meter. Dari pengukuran yang dilakukan diperoleh sebanyak 92 data untuk $n$ dari $n=1$ sampai $n=8$. Data yang diperoleh dari hasil pengukuran berupa data arus (I), beda potensial $(\Delta \mathrm{V})$, dan spasi tiap elektoda (a). Untuk memperoleh nilai hambatan jenis semu, dihitung menggunakan persamaan (2.9), dimana nilai (K) dihitung menggunakan pesamaan (3.1).

Untuk memperoleh data hambatan jenis air pengisi pori $(\rho \mathrm{w})$, diperlukan data pendukung berupa nilai daya hantar listrik (DHL) guna memberikan informasi untuk tahap interpretasi. Nilai tersebut diperoleh dari pengukuran daya hantar listrik yang dilakukan secara langsung menggunakan konduktivitimeter Xplorer GLX PS-2002 pada sumber mata air panas bumi di lokasi penelitian. Data tersebut digunakan untuk menentukan nilai faktor formasi batuan. Adapun hasil pengukuran DHL air ditunjukkan pada tabel di bawah ini.

Tabel 2 Hasil pengukuran daya hantar listrik (DHL)

\begin{tabular}{|c|c|c|c|}
\hline $\begin{array}{c}\text { Mata air } \\
\text { panas }\end{array}$ & $\begin{array}{c}\text { DHL } \\
\mu \mathrm{S} / \mathrm{cm}\end{array}$ & $\begin{array}{c}\rho \mathrm{\rho} \\
(\Omega \mathrm{m})\end{array}$ & $\begin{array}{c}\text { Keterangan } \\
\text { suhu }\left({ }^{\circ} \mathrm{C}\right)\end{array}$ \\
\hline MAP-1 & 788 & & 38 \\
\hline MAP-2 & 808 & \multirow{2}{*}{12,22} & 41 \\
\cline { 1 - 1 } MAP-3 & 858 & & 44 \\
\hline
\end{tabular}

Berdasarkan hasil pengukuran DHL, diperoleh nilai rata-rata dari hambatan jenis air pengisi pori $(\rho \mathrm{w})$ yaitu sebesar $12,22 \Omega \mathrm{m}$ ( Tabel 4.1). Nilai $\rho \mathrm{w}$ ini yang kemudian digunakan untuk menghitung nilai faktor formasi $(\mathrm{F})$ batuan untuk setiap bentangan menggunakan persamaan 2.2.

Secara umum, nilai hambatan jenis dan faktor formasi yang diperoleh mencerminkan adanya perbedaan litologi. Perbedaan tersebut di interpretasikan sebagai berikut:

1. Untuk lapisan 1 yang mempunyai hambatan jenis $<24,44 \Omega \mathrm{m}$ dengan faktor formasi $<2$ divisualisasikan dengan warna kuning, diduga merupakan lempung, lempung pasiran dan batu lumpur.

2. Untuk lapisan 2 yang mempunyai hambatan jenis 24,44 - 61,1 $\Omega \mathrm{m}$ divisualisasikan dengan warna hijau, lapisan ini diduga merupakan model aliran panas bumi di bawah permukaan dengan nilai faktor formasi 2-5 dan merupakan lapisan pasir lempung gambut dan tanah liat

3. Untuk lapisan 3 dengan hambatan jenis $>61,1 \Omega \mathrm{m}$ dengan nilai faktor formasi $>5$ divisualisasikan dengan warna biru, diduga sebagai lapisan batu gamping, batu pasir dan merupakan lapisan batuan keras.

Berikut disajikan hasil permodelan penampang 2-D hambatan jenis tiap lintasan menggunakan koreksi topografi dan penampang dengan perhitungan faktor formasi batuan.

\section{1) Lintasan 1}

Posisi pengukuran lintasan 1 berada pada koordinat $0^{\circ} 42^{\prime} 38^{\prime}$ ' LU dan $120^{\circ} 112^{\prime}$ '51', BT. Patok 1 lintasan ini berada pada ketinggian 126 meter di atas permukaan laut. Kondisi topografi yang menanjak menyebabkan patok 25 berada pada ketinggian $146 \mathrm{mdpl}$, dan membentang dari arah utara ke selatan $\left(\mathrm{N} 186^{\circ}\right)$, dengan akses menuju lokasi penelitian tidak dapat dilalui dengan menggunakan kendaraan. 
Hasil pemodelan penampang lintasan ini ditunjukkan pada Gambar 4 di bawah ini, dengan diperoleh tingkat kesalahan sebesar $9,6 \%$.

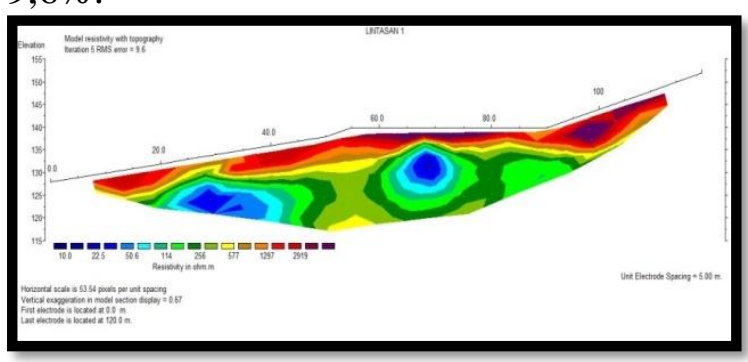

Gambar 4 Penampang Res2dinv 2-D hambatan jenis lintasan 1

Berdasarkan gambar penampang diatas kemudian dilakukan visualisasi menggunakan software Surferll dengan perhitungan faktor formasi batuan dan diperoleh penampang dengan model aliran panas seperti gambar berikut.

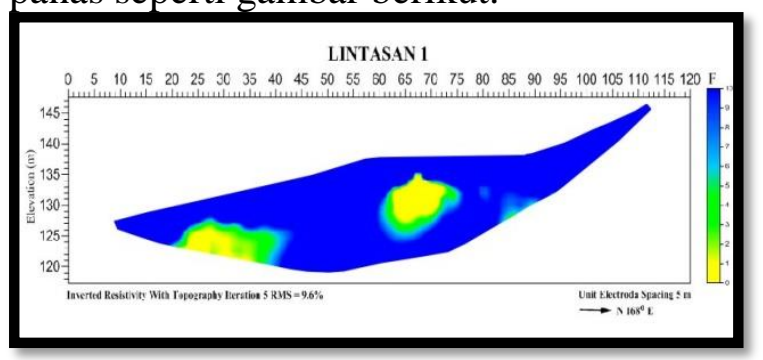

Gambar 5 Penampang 2-D faktor formasi batuan pada lintasan 1

Posisi lintasan 1 berada di perbukitan dengan kondisi topografi yang menanjak seperti pada gambar 5. Berdasarkan gambar di atas, terdeteksi adanya lapisan dengan nilai faktor formasi 2-5 yang mempunyai hambatan jenis sebesar 24,44 - 61,1 $\Omega \mathrm{m}$ ditunjukkan pada warna hijau. Lapisan tersebut dapat dilihat pada meteran 20 - 40 sampai kedalaman tak terhingga yang diduga merupakan aliran panas bumi. Selain itu, lapisan tersebut muncul kembali pada meteran 60 - 75 diduga merupakan ukuran lebar dari aliran panas bumi, disebabkan karena lintasan ini berpotongan langsung dengan lintasan 2 pada patok 13 yang mengukur secara langsung di lokasi munculnya mata air panas .

\section{2) Lintasan 2}

Posisi pengukuran lintasan 2 berada pada posisi $0^{\circ} 42^{\prime} 37^{\prime}$ ' LU dan $120^{\circ} 12^{\prime}$ 54" BT. Patok 1 lintasn ini berada pada ketinggian 151 mdpl, dan patok 25 berada pada ketinggian 147 mdpl. Perbedaan ketinggian tersebut disebabkan karena topografi di lokasi pengukuran bervariasi, sepeti yang terlihat pada Gambar 6. Lintasan ini membentang dari arah timur laut ke barat daya $\left(\mathrm{N} \mathrm{220^{ \circ } )}\right.$ dan hanya dapat di tempuh dengan berjalan kaki.

Lintasan 2 saling berpotongan dengan lintasan 1 pada patok 13, berada pada lokasi yang sama, namun memiliki arah bentangan yang berbeda. Keberadaan sumber panas bumi terdapat pada meteran 80 diukur secara langsung dengan memotong di lokasi tersebut pada patok ke 18 .

Hasil pemodelan penampang lintasan ini ditunjukkan pada Gambar 6 dengan tingkat kesalahan sebesar 7,8\%

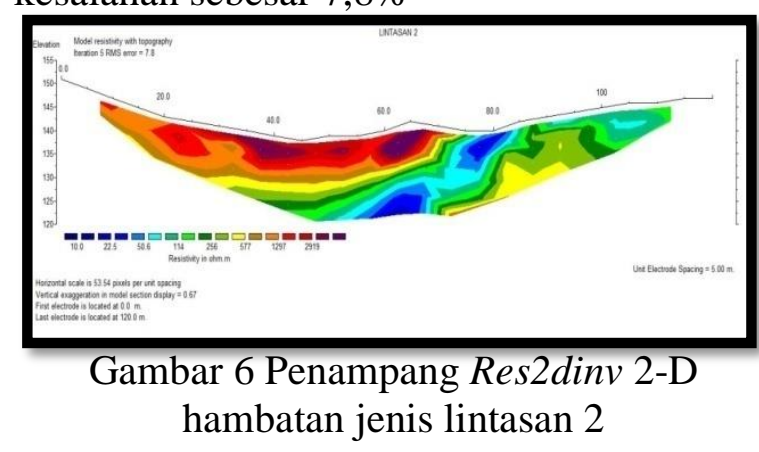

Berdasarkan gambar penampang diatas kemudian dilakukan visualisasi menggunakan software Surferl1 dengan perhitungan faktor formasi batuan dan diperoleh penampang dengan model aliran panas seperti gambar berikut.

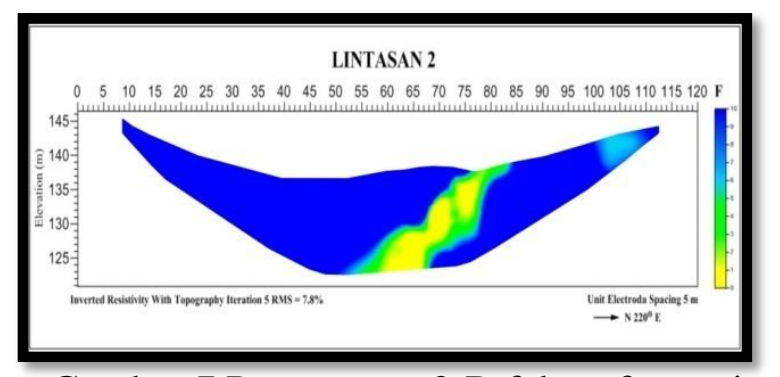

Gambar 7 Penampang 2-D faktor formasi batuan pada lintasan 2 
Posisi pengukuran lintasan 2 berada di perbukitan, dengan topografi yang bervariasi seperti pada gambar. Berdasarkan gambar 7 terdeteksi adanya lapisan dengan nilai faktor formasi 2-5 yang mempunyai hambatan jenis sebesar 24,44 - 61,1 $\Omega$ m ditunjukkan pada warna hijau. Lapisan tersebut terlihat pada meteran 76-85 yang merupakan aliran panas bawah yang kedalamannya sampai tidak terdeteksi di bawah permukaan. Dugaan tersebut diperkuat dengan dilakukannya pengukuran ini secara langsung persis memotong di lokasi sumber panas bumi, serta kesesuaian nilai DHL air panas yang diukur secara langsung sebagai data pendukung.

\section{3) Lintasan 3}

Lokasi pengukuran lintasan 3 berada pada posisi $0^{\circ} 42^{\prime} 39^{\prime}$ ' LU dan $120^{\circ} 12^{\prime}$ 51" BT. Patok 1 Lintasan ini berada pada ketinggian 108 mdpl, dan patok ke 25 berada pada ketinggian 126 mdpl. Dengan kondisi topografi yang menanjak dan arah bentangan dari utara ke selatan $\left(\mathrm{N} 200^{\circ}\right)$ dan hanya dapat ditempuh dengan berjalan kaki.

Hasil pemodelan lintasan 3 dapat dilihat pada Gambar 4.3 dengan tingkat kesalahan sebesar $7,8 \%$.

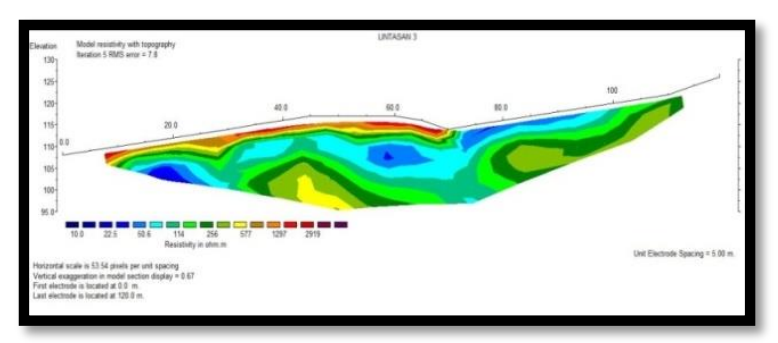

Gambar 8 Penampang Res2dinv 2-D hambatan jenis lintasan 3

Berdasarkan gambar penampang diatas kemudian dilakukan visualisasi menggunakan software Surferll dengan perhitungan faktor formasi batuan dan diperoleh penampang dengan model aliran panas seperti gambar berikut.

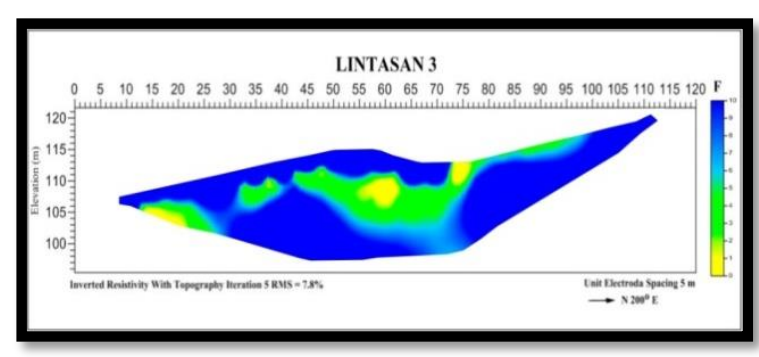

Gambar 9 Penampang 2-D faktor formasi batuan pada lintasan 3

Berdasarkan gambar 9 terdeteksi adanya lapisan dengan nilai faktor formasi 2-5 yang mempunyai hambatan jenis sebesar 24,44 $61,1 \Omega \mathrm{m}$ ditunjukkan pada warna hijau. Lapisan tersebut muncul pada meteran 12-27 yang jika dilihat dari posisnya bisa jadi merupakan aliran yang kedalamannya masih jauh sampai kebawah permukaan tetapi belum dapat terdeteksi. Selain itu, muncul kembali lapisan yang sama dengan dimensi yang lebih besar terlihat pada meteran 42 98 yang diduga merupakan aliran panas bawah permukaan yang nilai hambatan jenisnya sama dengan lintasan 2 .

\section{4) Lintasan 4}

Lokasi pengukuran lintasan 4 berada pada posisi $0^{\circ} 42^{\prime} 40^{\prime}$ ' LU dan $120^{\circ} 12^{\prime}$ '51" BT. Patok 1 Lintasan ini berada pada ketinggian 139 mdpl dan patok 25 berada pada ketinggian $136 \mathrm{mdpl}$. Kondisi topografi berada di daerah perbukitan dan di lembah. Arah bentangannya dari tenggara ke barat laut ( $\mathrm{N} 322^{\circ}$ ), serta dapat diakses menggunakan kendaraan. Lokasi pengukuran ini berada di sebelah utara atau berjarak sekitar $\pm 200 \mathrm{~m}$ dari posisi sumber panas bumi.

Hasil pemodelan lintasan 4 ditunjukkan pada gambar 4.4 berikut dimana diperoleh tingkat kesalahan sebesar 9,9\%.

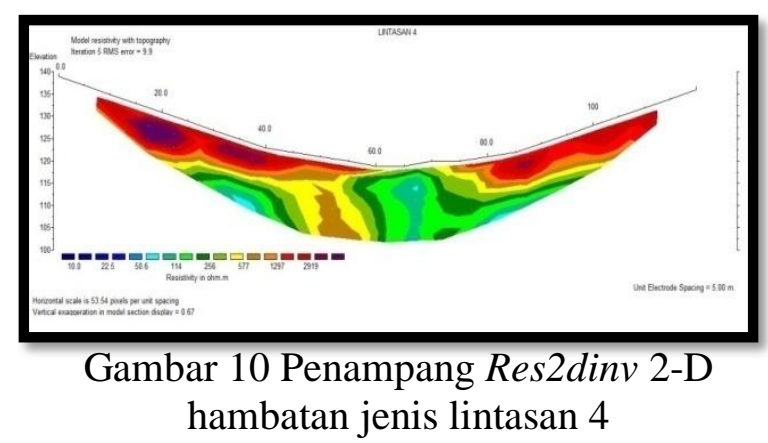


Berdasarkan gambar penampang diatas kemudian dilakukan visualisasi menggunakan software Surferll dengan perhitungan faktor formasi batuan dan diperoleh penampang dengan model aliran panas seperti gambar berikut.

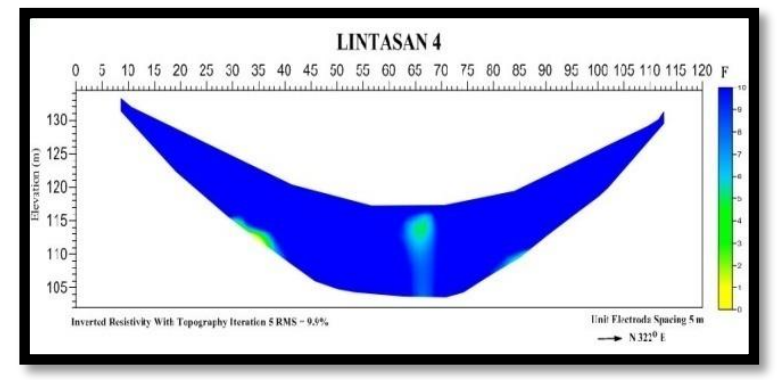

Gambar 11 Penampang 2-D faktor formasi batuan pada lintasan

Berdasarkan gambar 11 menunjukan distribusi nilai fakor formasi yang diperoleh. Pada meteran 27 - 37 hanya terlihat sedikit potongan lapisan berwarna hijau yang diduga merupakan aliran panas bumi. Berbanding terbalik seperti yang ditunjukkan pada gambar 4.6 dan 4.7, Lintasan ini hanya didominasi oleh lapisan 3 berwarna biru yang dimana nilai hambatan jenisnya $>61,1$ $\Omega \mathrm{m}$ dengan nilai faktor formai $>5$. Lapisan ini diduga merupakan lapisan batu gamping, batu pasir dan merupakan lapisan batuan keras. Berdasarkan kondisi dilapangan, lintasan ini merupakan lintasan yan paling jauh letaknya diantara lintasan lain dari lokasi sumber panas bumi.

Berdasarkan hasil interpretasi keseluruhan penampang diperoleh hasil bahwa, model aliran panas bumi bawah permukaan desa lemba harapan hanya terdapat pada lintasan 1, lintasan 2 dan lintasan 3 dengan nilai hambatan jenis sebesar 24,32 - 60,8 $\Omega \mathrm{m}$ dengan perhitungan nilai faktor formasi 2-5. Pada lintasan 1 , terdeteksi model aliran panas pada meteran 60 - 75 yang diduga merupakan ukuran lebar dari aliran panas bawah permukaan pada lintasan 2, Dimana lintasan tersebut saling berpotongan satu sama lain. Sedangkan pada lintasan 2 diperoleh model aliran panas bumi di bawah permukaan yang terlihat pada meteran 77 -
85 , diperkuat dengan adanya data pendukung berupa nilai DHL yang nantinya digunakan untuk menghitung nilai hambatan jenis tiaptiap lintasan, serta dilakukannya perhitungan faktor formasi batuan. Pada lintasan 3, terdeteksi adanya lapisan yang merupakan aliran panas bumi yang memiliki nilai hambatan jenis 24,32 - 60,8 $\Omega \mathrm{m}$ berada pada meteran 12- 27, kemudian muncul kembali pada meteran 42 - 98. Sedangkan pada lintasan 4 tidak terdeteksi adanya aliran panas bumi berdasarkan gambar penamang dengan menggunakan perhitungan faktor formasi batuan.

\section{KESIMPULAN DAN SARAN}

Berdasarkan hasil interpretasi dan penelitian di Desa Lemba Harapan Kabupaten Tolitoli dapat disimpulkan bahwa model aliran panas bumi bawah permukaan desa lemba harapan hanya terdapat pada lintasan 1 , lintasan 2 dan lintasan 3 dengan nilai hambatan jenis sebesar 24,32 - 60,8 $\Omega \mathrm{m}$ dengan perhitungan nilai faktor formasi 2-5 dimana pada lintasan 1 ditemukan ukuran lebar dari aliran panas bumi tersebut yang berhubungan dengan lintasan 2. Pada lintasan 2 ditemukan aliran panas bumi dengan arah bentangan dari timur laut ke barat daya. keberadaan aliran panas bumi juga terdapat pada lintasan 3, dimana memiliki nilai hamnbatan jenis yang sama dan divisualisasikan dengan warna hijau, menggunakan perhitungan nilai faktor formasi batuan. Sedangkan pada lintasan 4 berdasarkan hasil dari penampang faktor formasi tidak ditemukan adanya aliran panas bumi.

\section{SARAN}

Sebaiknya pada saat melakukan penelitian selanjutnya tidak lupa membawa sumber arus listrik (accu) tambahan sebagai antisipasi dan sebagai cadangan serta membawa terpal untuk tempat berteduh demi keselamatan alat serta perlu dilakukan penelitian selanjutnya menggunakan konfigurasi/metode yang lain, guna mendapatkan informasi tambahan tentang 
kedalaman aliran, serta darimana saja sumber panas bumi tersebut berasal.

\section{UCAPAN TERIMA KASIH}

Trimakasih kepada Jurusan Fisika FMIPA UNTAD yang sudah memfasilitasi dalam penyelesaian tugas akhir ini.Trimakasih juga buat bapak dosen pembimbing dan pembahas yang sudah memberikan saran-saran dalam penyempurnaan tulisan ini.Trimakasih buat teman-teman, kaka-kaka senior, dan adik junior di jurusan Fisika FMIPA UNTAD yang sudah membantu dalam penelitian ini.

\section{DAFTAR PUSTAKA}

[Bakosurtanal] Badan Koordinasi Survey dan Pemetaan Nasional (1991). Peta Rupa Bumi Indonesia. Edisi ke-1. Jalan Raya Jakarta-bogor KM 46

Djaelani., A (2015). Identifikasi Sebaran Panasbumi Menggunakan Metode Geolistrik Hambatan Jenis di Desa Wani Tiga.Skripsi.Fakultas Matematika dan Ilmu Pengetahuan Alam,Universitas Tadulako.Palu

Haeruddin, N., Rasimeng, S., dan Yuliana E. (2008). Metode Geolistrik Untuk Menentukan Pola Penyebaran Fluida Gheotermal di Daerah Potensi Panasbumi Gunung Rajabasa kalianda Lampung Selatan.Jurnal fisika FMIPA volume 2. Universitas Lampung.

Ilyas, Z. (2012). Seminar Nasional VIII SDM Teknologi Nuklir (ISSN P9780176). Yogyakarta
Lange, O., dan Labedeva, N. (1991). Geologi Umum. Gaya Media Pratama. Jakarta.

Minarto, E. (2007). Pemodelan Inversi Data Geolistrik Untuk Menentukan Struktur Perlapisan Bawah permukaan Daerah Panasbumi Mataloko. Jurnal Geofisika. Surabaya.

Moedioyono. (2010). Pembangunan Pembangkit Listrik Tenaga Panasbumi (PLTPB) Universitas Diponegoro. Semarang.

Prameswari, L. (2004). Aplikasi Metode Resistivitas Batuan dengan Menggunakan Parameter Dark Zarrouk dan Konsep Anisotropi, jurnal Sains dan Seni Its, Vol 1, No 1, PP, 15-20

Suhartono, N., (2012). Pola Sistim Panas dan Jenis Geothermal dalam Estimasi Cadangan Daerah Kamojang. jurnal ilmiah MTG, 5(2).

Taib, Tachyudin M.I (1999). Eksplorasi Geolistrik. Institut Teknologi Bandung. Bandung.

Telford, W., M., Geldart, L., P., and Sheriff, R..(1990). Applied Geophysics.Second edition.Cambridge University

Wati. (2015). Aplikasi Metode Geolistri Kuntuk Menentukan Sebaran Panas Bumi di Desa Mapane Tambu. Universitas Tadulako. Palu 